\title{
Wybrane wskaźniki zachowań Rosjan na rynku polskim ze szczególnym uwzględnieniem rynku rolno-spożywczego w latach 2010-2017
}

\section{Selected Factors of Russian Behavior on the Polish Market with Particular Regard to the Agri-Food Market in 2010-2017}

\begin{abstract}
Synopsis. Celem opracowania jest analiza wybranych wskaźników ilustrujących zachowania Rosjan na rynku polskim ze szczególnym uwzględnieniem rynku rolno-spożywczego, oraz wskazanie najważniejszych zmian jakie zaszły w latach 2010-2017. Do weryfikacji założeń wykorzystano analizę ruchu granicznego, celu i częstotliwości przyjazdów Rosjan do Polski, a także wielkości i struktury wydatków poniesionych przez Rosjan w Polsce w analizowanym okresie. Artykuł jest wynikiem analizy literatury i opracowań statystycznych. Do analizy danych wykorzystano metody: opisową, szeregów czasowych oraz wnioskowania.

Ruch graniczny na granicy polsko-rosyjskiej charakteryzuje zmienność dynamiki przyjazdów Rosjan do Polski, na którą wpływ mają m.in. przepisy regulujące zasady funkcjonowania ruchu granicznego między Rzeczypospolitą Polską a Federacją Rosyjską, relacje cenowe pomiędzy sąsiadującymi krajami oraz niestabilna sytuacja międzynarodowa. Wszelkie zmiany przepisów regulujących przepływ towarów i usług na granicy polsko-rosyjskiej, znalazły odzwierciedlenie w celu i częstotliwości przyjazdów Rosjan do Polski oraz w wysokości wydatków poniesionych w Polsce.
\end{abstract}

Slowa kluczowe: Federacja Rosyjska, rynek przygraniczny, konsument, embargo, wydatki

\begin{abstract}
The aim of the study is to analyze selected indicators defining the behavior of Russians on the Polish market with particular regard to the agri-food market, and to identify the most important changes that have occurred between 2010-2017. To verify the assumptions, the analysis of border traffic, purpose and frequency of arrivals of Russians to Poland was used, as well as the size and structure of expenses incurred by the Russians in Poland in the analyzed period. The article is the result of an analysis of literature and statistical studies. Data analysis was based on: descriptive methods, time series and inference.

Border traffic on the Polish-Russian border is characterized by the variability of the dynamics of Russian arrivals to Poland, influenced by the regulations governing the functioning of border traffic between the Republic of Poland and the Russian Federation, price relations between neighboring countries and the international situation. All changes to the regulations governing the flow of goods and services on the Polish-Russian border were reflected in the purpose and frequency of arrivals of Russians to Poland and in the amount of expenses incurred by them in Poland.
\end{abstract}

Key words: the Russian Federation, cross-border market, consumer, embargo, expenses

JEL Classification: A13, D12, Z13

\footnotetext{
${ }^{1}$ dr inż., Wydział Nauk Ekonomicznych UW-M w Olsztynie, ul. M. Oczapowskiego 4, 10-719 Olsztyn, e-mail: iwona.batyk@uwm.edu.pl; https://orcid.org/0000-0002-6230-7441
} 


\section{Wprowadzenie}

Analizując zachowania Rosjan na rynku polskim, należy skoncentrować się na zagadnieniach dotyczących oddziaływania zewnętrznych i wewnętrznych uwarunkowań kształtujących te zachowania. Wszelkie przesłanki zmian w zachowaniach konsumentów rosyjskich, zależne są przede wszystkim od polityki gospodarczej i społecznej w obszarze konsumpcji, funkcjonowania gospodarki rynkowej, a także od procesów integracyjnych w Europie. Wskazane procesy i zjawiska prowadzą do przewartościowania działań i zachowań mieszkańców obszarów przygranicznych, ich celów, dążeń, aspiracji i wartości. Zachowania Rosjan są efektem oddziaływania nowych wzorców i trendów, a także możliwości jakie pojawiły się w związku z funkcjonowaniem małego ruchu granicznego.

Celem podjętych rozważań jest analiza wybranych wskaźników ilustrujących zachowania cudzoziemców przekraczających granicę polsko-rosyjską i deklarujących Federację Rosyjską jako kraj stałego zamieszkania (dalej: Rosjan) na rynku polskim, ze szczególnym uwzględnieniem rynku rolno-spożywczego. Wskazano najważniejsze zmiany jakie zachodziły w zachowaniach Rosjan w latach 2010-2017.

\section{Uwarunkowania determinujące zachowania Rosjan na rynku polskim}

W funkcjonowaniu rynków przygranicznych istotną rolę odegrał mały ruch graniczny między Rzeczypospolitą Polską a Federacją Rosyjską, który obowiązywał od 27 lipca 2012 r. do 4 lipca 2016 r. Umowa o zasadach małego ruchu granicznego (Umowa..., 2011) definiuje ten ruch jako wielokrotne przekraczanie polsko-rosyjskiej granicy państwowej przez mieszkańców strefy przygranicznej Państwa jednej Strony w celu przebywania w strefie przygranicznej Państwa drugiej Strony, dla podtrzymywania więzi rodzinnych, społecznych, kulturalnych, a także uzasadnionych kontaktów ekonomicznych i innych, które nie są uznawane za zatrudnienie lub działalność zarobkową. Za mieszkańców strefy przygranicznej zostali uznani mieszkańcy Obwodu Kaliningradzkiego, a po stronie polskiej: mieszkańcy Gdańska, Gdyni, Sopotu, Olsztyna i Elbląga oraz powiatów: gdańskiego, nowodworskiego, malborskiego i puckiego, elbląskiego, braniewskiego, lidzbarskiego, bartoszyckiego, olsztyńskiego, kętrzyńskiego, mragowskiego, giżyckiego, węgorzewskiego, gołdapskiego i oleckiego. Precedensem w historii Unii Europejskiej było rozszerzenie strefy przygranicznej po obu stronach granicy powyżej $50 \mathrm{~km}$ od linii granicy (Żukowski, 2013).

Mały ruch graniczny na granicy polsko-rosyjskiej można rozpatrywać w wymiarze ekonomicznym i pozaekonomicznym, korzystnym i niekorzystnym, kontrolowanym i żywiołowym, jednakże niezależnie od wymiaru, przyczynił się on do zmian w zachowaniach Rosjan na polskim rynku przygranicznym. W okresie jego obowiązywania nie uległy zmianie przepisy celne regulujące przewóz towarów przez granicę, jednakże wielokrotne (bardzo często codzienne przyjazdy Rosjan do Polski) umożliwiły przewóz towarów w ilościach przekraczających indywidualne potrzeby. Handlowcy z Obwodu Kaliningradzkiego wykazali, że konkurencja w postaci handlu ulicznego towarami przywiezionymi z Polski, doprowadziła do zmniejszenia ich obrotów o około $30 \%$. Szacowali oni, że dzienna sprzedaż polskich towarów bezpośrednio z samochodów, sięgała nawet 10 ton (Szczepanik, 2013). 
Na zachowania konsumentów rosyjskich wpływała niepewność rozwoju sytuacji geopolitycznej. Wzrost płac jaki nastapił pod koniec 2014 r. był poniżej poziomu inflacji, i spowodował znaczne zmniejszenie wydatków na zakup dóbr konsumpcyjnych. W konsekwencji tego nastapiło spowolnienie gospodarcze Federacji Rosyjskiej, w której coraz bardziej nasila się kryzys konsumpcji (Anczakowska, 2016). W związku ze spadkiem wartości rosyjskiej waluty, jaki miał miejsce pod koniec 2014 r., nastapił wzrost cen importowanych surowców i komponentów, który spowodował obniżenie konkurencyjności rodzimych produktów. W wyjaśnieniu tego zjawiska, należy przyjać założenie, na które zwrócił uwagę Barczyk (2014), iż popyt na każdym rynku lokalnym, w każdym okresie będzie pośrednio kształtowany przez zachowania konsumentów i producentów z innych rynków. Zmniejszyło się także zaufanie rosyjskich konsumentów do sektora rolnospożywczego w Rosji (Сельское хозяйство в России..., 2014), czego skutkiem było ograniczenie produkcji na terenie Obwodu Kaliningradzkiego, a nawet likwidacja przedsiębiorstw. Bezpieczeństwo żywnościowe Obwodu Kaliningradzkiego w istotnym stopniu warunkuje zachowania konsumentów, a także wpływa na poziom zróżnicowania międzyregionalnego oraz dostępność do towarów przywożonych z zagranicy. Formułowane przez ekspertów rosyjskich zalecenia prowadzące do poprawy bezpieczeństwa żywnościowego Obwodu Kaliningradzkiego dotyczyły przede wszystkim: zapewnienia większego dostępu do żywności, rozwoju rynku surowców i sieci sprzedaży, doskonalenia narzędzi kontroli jakości surowców i produktów żywnościowych, stworzenia certyfikacji systemów zarządzania jakością oraz wydajnością pracy (Никифорова, Огнева, 2014). Wartość progowa importu zapewniającego bezpieczeństwo żywnościowe w Obwodzie Kaliningradzkim, nie powinna przekraczać $25 \%$. W 2012 r., import żywności do eksklawy kształtował się na poziomie ponad 40\% (Лукьянова, 2015). W $2013 \mathrm{r}$. import produktów żywnościowych utrzymał się na tym samym poziomie co rok wcześniej (Никифорова, 2015). Obwód Kaliningradzki uzależniony jest od importu żywności i surowców rolnych $\mathrm{z}$ innych rosyjskich regionów oraz z zagranicy. Po wprowadzeniu przez Federację Rosyjską w 2014 r. sankcji na towary rolno-spożywcze z krajów Unii Europejskiej, problem zapewnienia bezpieczeństwa żywnościowego w Obwodzie Kaliningradzkim pogłębia się.

Wstrzymanie importu do Rosji spowodowało brak dostępności do towarów rolnospożywczych w legalnym handlu detalicznym. Embargo nie wpłynęło na całkowity brak polskich towarów na rynku rosyjskim. Paradoksalnie, zwiększyła się dostępność do nich w handlu przygranicznym, w którym ceny produktów pochodzących z Polski były kilkakrotnie niższe, od cen towarów oferowanych w rosyjskich placówkach handlowych.

Spadek wartości rosyjskiej waluty, nie wpłynął w znaczący sposób na obniżenie konkurencyjności polskich towarów względem wyrobów rodzimych. Rosjanie, pomimo niekorzystnego dla nich kursu rubla, preferowali zakupy w Polsce, gdzie mogli nabyć wiele towarów w promocyjnych cenach. Produkty spożywcze pochodzące z Polski, w opinii konsumentów rosyjskich posiadają uznaną renomę, nie tylko ze względu na atrakcyjną cenę, ale również ze względu na zdecydowanie wyższą jakość, w porównaniu z produktami rodzimymi. Nawet po wielu medialnych doniesieniach o zakwestionowaniu jakości produktów żywnościowych pochodzących z Polski przez rosyjskie służby kontroli sanitarnej z powodu braku spełnionych rosyjskich norm fitosanitarnych, zainteresowanie konsumentów rosyjskich zakupem tych produktów nie uległo zmniejszeniu.

Na zmiany w zachowaniach konsumentów z Obwodu Kaliningradzkiego dotyczące struktury nabywanych $\mathrm{w}$ Polsce towarów oraz ich przeznaczenia, wpłynęły przede wszystkim przepisy rosyjskiej służby celnej, określające możliwość jednorazowego wwozu 
do Federacji Rosyjskiej produktów spożywczych zakupionych w Polsce. Przepisy Federalnego Urzędu Celnego określają towary przeznaczone do użytku osobistego, przewożone przez granicę celną, które zwolnione są z opłat celnych. Bez zgłoszenia i opłat celnych, na terytorium Federacji Rosyjskiej można wwozić m.in.: towary o wartości nieprzekraczającej 1500 euro oraz łącznej wadze do $50 \mathrm{~kg}$; do $5 \mathrm{~kg}$ gotowych produktów pochodzenia zwierzęcego w hermetycznie zamkniętym opakowaniu; do $5 \mathrm{~kg}$ owoców morza; do $250 \mathrm{~g}$ kawioru $\mathrm{z}$ jesiotra; 3 litry napojów alkoholowych (dla osób w wieku powyżej 18 lat); 200 papierosów, 50 cygar lub $0,25 \mathrm{~kg}$ tytoniu (dla osób w wieku powyżej 18 lat); środki pieniężne i (lub) czeki podróżne o łącznej wartości nieprzekraczającej równowartości 10000 dolarów USD oraz leki w ilości niezbędnej do użytku osobistego (Товары для личного..., 2015). Ograniczenia ilości towarów do $5 \mathrm{~kg}$ mają zastosowanie jedynie do produktów pochodzenia zwierzęcego, natomiast pozostałe artykuły spożywcze, takie jak: wyroby cukiernicze, produkty zbożowe, marynaty, koncentraty spożywcze, kawa i herbata czy przyprawy można wwozić do Federacji Rosyjskiej w ilości nieprzekraczającej $50 \mathrm{~kg}$ na osobę.

Konsumpcja jest konkretnym i dającym się łatwo zaobserwować zachowaniem i uwzględnia różnorodne potrzeby, nawet takie jak: kreowanie wizerunku i zamożności poprzez zakup dóbr luksusowych czy doświadczanie nieznanych doznań i wrażeń. Z badań przeprowadzonych w 2017 r. przez międzynarodową agencję marketingową Nielsen wynika, że konsumenci rosyjscy bardzo często kupowali produkty impulsywnie, dużą wagę przywiązywali do jakości produktu oraz wykazywali silną lojalność wobec marki. Na zakupy przeznaczali oni ponad $80 \%$ dochodu, a ze względu na brak zaufania do systemu bankowego nie byli skłonni do oszczędzania. Konsumenci rosyjscy byli bardzo dobrze zorientowani $\mathrm{w}$ ofercie i możliwościach wyboru i często przed wejściem do centrum handlowego wiedzieli co chcą kupić. Na zwyczaje zakupowe Rosjan silny wpływ wywierała rodzina, 53\% Rosjan dokonywało regularnych zakupów dla całej rodziny, a tylko $32 \%$ przeznaczało zakupione towary na własny użytek (Russia: Reaching the consumer, 2017). Zachowania Rosjan na polskim rynku towarów rolno-spożywczych determinowane były opinią innych użytkowników. Kasouf i Nikitina (2013) twierdza, że Rosjanie podejmowali decyzje nabywcze na podstawie wiedzy i informacji o produkcie oraz relacji przekazywanych przez innych użytkowników, zarówno rodzinę i znajomych, jak również informacji dostępnych w Internecie.

Procesy globalizacji i integracji, umożliwiające swobodny przepływ wzorców cywilizacyjnych, stylów życia i konsumpcji sprzyjają upowszechnieniu się postaw konsumpcyjnych wśród konsumentów z Obwodu Kaliningradzkiego. Dynamiczny rozwój konsumpcjonizmu widoczny jest w krajach, które przebudowują swoje gospodarki. Rosjanie dążą do podniesienia poziomu życia, do zmniejszenia dystansu cywilizacyjnego w stosunku do krajów Europy Zachodniej. Naturalne dążenie do poprawy warunków życia przeradza się w pogoń za dobrami konsumpcyjnymi, których posiadanie staje się wartością samą w sobie (Grzega, Kieżel, 2017). Zamożność konsumentów w dużej mierze przyczynia się do kreowania nowych trendów w konsumpcji, a nowość i oryginalność towarów są ważnymi atrybutami oferty rynkowej. Według Garbarskiego i in. (2000) rolę wzorcotwórczą wyznaczającą nowe mody w konsumpcji, pełni zamożniejsza czesść konsumentów.

Siła oddziaływania czynników demograficznych na postawy etnocentryczne konsumentów, jest zależna od kraju, rozwoju gospodarczego, cywilizacyjnego i kulturowego. Badania międzynarodowe wskazują na korelację dodatnią między 
etnocentryzmem konsumenckim a patriotyzmem (Zhou i in., 2010). Odnosząc się do stopnia rozwoju kraju, rezultaty badań wskazują, że konsumenci z krajów bardziej rozwiniętych preferują produkty pochodzenia krajowego w porównaniu z importowanymi. Identyfikują bardziej negatywne odczucia $\mathrm{W}$ stosunku do produktów $\mathrm{z}$ krajów rozwijających się lub słabo rozwiniętych niż z krajów wysoko rozwiniętych (Samiec, 1994; Reardon i in., 2005). W krajach o niższym poziomie rozwoju produkty zagraniczne sa najczęściej wyżej oceniane od rodzimych, a konsumenci chętniej je nabywają (Kaynak in., 2000; Wang, Chen, 2004; Sharma, Wu, 2015).

\section{Dane i metody}

Zakres czasowy badań został zdeterminowany dostępnością kompletnych i porównywalnych danych. Źródłem danych do analizy i wnioskowania były informacje pochodzące z opracowań Głównego Urzędu Statystycznego, Urzędu Statystycznego w Rzeszowie oraz Komendy Głównej Straży Granicznej i Krajowej Administracji Skarbowej w Olsztynie. Wykorzystano dane wtórne, które opracowano przy wykorzystaniu metod: opisowej, szeregów czasowych oraz logicznego wnioskowania.

Analizę danych przeprowadzono w układzie horyzontalnym i wertykalnym, pozwalającym na zbadanie struktury analizowanych wskaźników w przyjętym do badań okresie. Do prezentacji wyników wykorzystano analizę zmian w czasie dotyczącą wielkości ruchu granicznego, celu oraz częstotliwości przyjazdów Rosjan do Polski. Zaprezentowano analizę wydatków ponoszonych przez Rosjan w Polsce w analizowanym okresie oraz ich strukturę, a także liczbę i wartość rachunków Tax Free zgłoszonych przez Rosjan na granicy polsko-rosyjskiej. W analizach zastosowano wskaźniki łańcuchowe i zaprezentowano przyrosty względne. Uzyskane wyniki przedstawiono w postaci tabelarycznej.

\section{Wyniki badań}

Ze statystyk Komendy Głównej Straży Granicznej, wynika wzrost intensywności ruchu granicznego na polsko-rosyjskiej granicy w latach 2010-2014 oraz spadek liczby Rosjan przyjeżdżających do Polski w latach 2015-2016 (Tab. 1).

Zmiany przepisów dotyczących zasad przekraczania granicy znalazły odzwierciedlenie w poziomie natężenia ruchu granicznego. W okresie od 27 lipca 2012 do 4 lipca 2016 r., czyli przez niespełna cztery lata funkcjonowania małego ruchu granicznego, do Polski wjechało 2386739 cudzoziemców posiadających stosowne zezwolenie. Zaobserwowano bardzo dużą dynamikę liczby cudzoziemców przekraczających granicę polsko-rosyjską. Od lipca 2012 r. do końca 2014 r., następował wzrost liczby Rosjan wjeżdżających do Polski w ramach małego ruchu granicznego. Od 2015 r. zmniejszyła się liczba cudzoziemców przekraczających granicę polsko-rosyjską, a tendencja spadkowa dotyczyła zarówno ruchu granicznego ogółem, jak i małego ruchu granicznego.

Dynamika ruchu granicznego na granicy polsko-rosyjskiej zależna była od zmian przepisów dotyczących przekraczania granicy. Pomimo zawieszenia małego ruchu granicznego, w 2017 r. odnotowano wzrost liczby Rosjan przekraczających granice polskorosyjską. Wynika z tego, iż Polska jest dla nich nadal atrakcyjną destynacją, a procedury 
wizowe oraz opłaty z nimi związane, nie stanowią czynnika ograniczającego przyjazdy Rosjan do Polski. Posiadanie wizy Schengen uprawnia do pobytu nie tylko na obszarze objętym małym ruchem granicznym, ale także umożliwia korzystanie $\mathrm{z}$ oferty handlowousługowej w całej Polsce.

Tabela 1. Ruch graniczny Rosjan do Polski w latach 2010-2017

Table 1. Border traffic of Russians to Poland in 2010-2017

\begin{tabular}{l|cccc}
\hline & $\begin{array}{c}\text { Ruch graniczny } \\
\text { (tys. osób) }\end{array}$ & $\begin{array}{c}\text { Dynamika ruchu } \\
\text { granicznego }\end{array}$ & $\begin{array}{c}\text { W tym mały ruch } \\
\text { graniczny } \\
\text { (tys. osób) }\end{array}$ & $\begin{array}{c}\text { Dynamika małego } \\
\text { ruchu granicznego }\end{array}$ \\
\hline 2010 r. & 431746 & 27,2 & - & - \\
2011 r. & 668476 & 54,8 & - & - \\
2012 r. & 1015384 & 51,9 & 13734 & 4124,4 \\
2013 r. & 1648531 & 62,4 & 580176 & 44,3 \\
2014 r. & 1670965 & 1,4 & 837167 & $-21,2$ \\
2015 r. & 1371407 & $-17,9$ & 659414 & $-55,0$ \\
2016 r. & 1162979 & $-15,0$ & 296248 & - \\
2017 r. & 1274278 & 9,6 & - & \\
\hline
\end{tabular}

Źródło: opracowanie własne na podstawie statystyk Komendy Głównej Straży Granicznej.

Zmiany zachowań Rosjan dotyczyły celu ich przyjazdu do Polski (Tab. 2). W latach 2010-2016 głównym powodem przyjazdów były zakupy. Do 2015 r., w każdym kolejnym roku zwiększał się udział osób deklarujących ten cel, a największy wzrost (o 14,4\%) nastapił w 2013 r. W 2016 r. odnotowano spadek o 2,6\% udziału Rosjan przyjeżdżających do Polski w celach zakupowych. Opracowania Głównego Urzędu Statystycznego dotyczące 2017 r. nie zawierają danych określających cel przyjazdów Rosjan do Polski.

Tabela 2. Cel przyjazdów Rosjan do Polski w latach 2010-2016

Table 2. The purpose of Russians arriving in Poland in 2010-2016

\begin{tabular}{|c|c|c|c|c|c|c|c|}
\hline \multirow{2}{*}{$\begin{array}{c}\text { Cel } \\
\text { przyjazdów }\end{array}$} & \multicolumn{7}{|c|}{ Rok } \\
\hline & 2010 & 2011 & 2012 & 2013 & 2014 & 2015 & 2016 \\
\hline Zakupy & 27,7 & 36,5 & 44,7 & 59,1 & 60,2 & 68,2 & 65,6 \\
\hline Turystyczny & 24,8 & 22,1 & 21,3 & 16,0 & 19,4 & 13,4 & 11,9 \\
\hline Tranzyt & 26,0 & 20,4 & 17,8 & 13,9 & 10,7 & 9,3 & 12,1 \\
\hline $\begin{array}{l}\text { Praca i } \\
\text { biznes }\end{array}$ & 13,1 & 12,5 & 10,5 & 6,0 & 3,8 & 3,8 & 4,4 \\
\hline $\begin{array}{l}\text { Odwiedziny } \\
\text { krewnych }\end{array}$ & 4,3 & 4,5 & 3,1 & 2,5 & 3,2 & 3,2 & 3,2 \\
\hline Leczenie & 0,5 & 0,4 & 0,5 & 0,5 & b.d. & b.d. & b.d. \\
\hline Inne & 3,6 & 3,6 & 2,1 & 2,0 & 2,7 & 2,1 & 2,8 \\
\hline
\end{tabular}

Źródło: opracowanie własne na podstawie danych GUS (Ruch graniczny oraz przepływ...: 2011, 2012, 2013, Ruch graniczny oraz wydatki...: 2014, 2015, 2016, 2017). 
W latach 2010-2016, wraz ze wzrostem zainteresowania przyjazdami do Polski w celach handlowych, zmniejszył się o $12,9 \%$ udział Rosjan przyjeżdżających w celach turystycznych. W analizowanym okresie, zmniejszył się o 13,9\% udział cudzoziemców deklarujących tranzyt oraz o 8,7\% - podróżujących w celach służbowych.

Jak wynika z badań przeprowadzonych przez Studzińską i Rzyskiego (2015), wprowadzenie małego ruchu granicznego okazało się dużym potencjałem dla rozwoju transgranicznej aktywności zakupowej w polskiej strefie przygranicznej. Turystyka zakupowa stała się jednym $\mathrm{z}$ najlepiej rozwijających się rodzajów aktywności transgranicznych na pograniczu polsko-rosyjskim. Doświadczenie zakupów i podróżowania przez granice bez żadnych ograniczeń jest stosunkowo nowym zjawiskiem dla społeczeństw w Europie Środkowej i Wschodniej. Kluczowym czynnikiem motywującym do przyjazdu do Polski w celu dokonania zakupów, były konkurencyjne ceny. Różnice w poziomie cen towarów i wysokości dochodów mieszkańców miejscowości przygranicznych wpływają na rozwój handlu (Powęska, 2011). Jak wynika z badań Fundacji im. Stefana Batorego przeprowadzonych w 2007 r., jednym z głównych celów przekraczania granic unijno-rosyjskich było dokonywanie zakupów w sąsiednich krajach (Monitoring..., 2008). Z analizy przeprowadzonej przez Powęską (2014), wynika, że w latach 2010-2012 struktura nierejestrowanych zakupów w Polsce obywateli rosyjskich wskazywała w większym zakresie na charakter konsumpcyjny niż inwestycyjny zastosowania zakupionych towarów.

Formy promocji związane z ceną były głównym instrumentem przyciągania klientów z Obwodu Kaliningradzkiego, jednakże zachętą do korzystania z oferty polskiego rynku rolno-spożywczego były także dogodne położenie oraz mała odległość w odniesieniu do granicy polsko-rosyjskiej. Z badań Gruenewalda i in. (2002) wynika, że bliskość miejsc, w których oferowane są dane produkty, sprzyja zwiększonej ich konsumpcji. Wyniki badań zawarte w raporcie pt. Consumer Behaviour in Russia, wskazuja, iż Rosjanie preferuja dokonywanie zakupów towarów rolno-spożywczych w supermarketach (43\%) lub hipermarketach (38\%). Najważniejszymi motywami wyboru placówki handlowej są: szeroki wybór towarów, łatwa dostępność do sklepu oraz korzystny stosunek jakości do ceny. W dalszej kolejności, istotne dla Rosjan przy wyborze miejsca zakupu, okazały się takie elementy, jak: dostępność do większości grup towarów w jednym sklepie, przyjazna atmosfera zakupów oraz kompetentna i uprzejma obsługa (Pesu, 2013).

W okresie obowiązywania przepisów umowy o małym ruchu granicznym, zaobserwowano wzmożony handel przygraniczny towarami rolno-spożywczymi w regionach objętych tym ruchem. W dwóch pierwszych latach, handel przygraniczny miał charakter hurtowy. Mimo dużego natężenia ruchu granicznego brało w nim udział relatywnie mało osób, które wielokrotnie przekraczały granicę polsko-rosyjską.

Wraz ze zmianą celu przyjazdu zmieniała się częstotliwości przyjazdów Rosjan do Polski (Tab. 3). W 2010 r. ponad połowa (55,2\%) deklarowała przyjazdy kilka razy w tygodniu. Odnotowano duży udział cudzoziemców przyjeżdżających codziennie. W 2011 r. udział Rosjan deklarujących przyjazdy kilka razy w tygodniu zmniejszył się o 28,4\%, natomiast zwiększył się o 14,3\% udział cudzoziemców przyjeżdżających do Polski kilka razy w miesiącu. W 2012 r., pomimo wprowadzenia małego ruchu granicznego, nastapił dalszy spadek udziału Rosjan najczęściej odwiedzających nasz kraj oraz wzrost o 8,2\% cudzoziemców deklarujących przyjazdy kilka razy w miesiącu. W 2013 r. odnotowano dalszy wzrost (o 14,6\%) udziału Rosjan przekraczających granicę polsko-rosyjską kilka razy w miesiącu, przy jednoczesnym zmniejszeniu się o 4,7\% udziału osób odwiedzających 
nasz kraj kilka razy w tygodniu. W 2013 r. większość Rosjan przyjeżdżających do Polski na zasadach małego ruchu granicznego, przekraczała granicę kilka razy w miesiącu $(66,1 \%)$, natomiast co czwarty cudzoziemiec $(25,9 \%)$ przyjeżdżał kilka razy w tygodniu (Ruch graniczny oraz wydatki..., 2014).

Tabela 3. Częstotliwość przyjazdów Rosjan do Polski w latach 2010-2016

Table 3. Frequency of arrivals of Russians to Poland in 2010-2016

\begin{tabular}{l|ccccccc}
\hline \multicolumn{1}{c}{$\begin{array}{c}\text { Częstotliwość } \\
\text { przyjazdów }\end{array}$} & 2010 & 2011 & 2012 & 2013 & 2014 & 2015 & 2016 \\
\hline $\begin{array}{l}\text { Codziennie } \\
\text { Kilka razy w } \\
\text { tygodniu }\end{array}$ & 4,4 & 1,7 & 1,1 & 1,2 & 0,8 & 1,3 & 0,7 \\
$\begin{array}{l}\text { Kilka razy w } \\
\text { miesiącu }\end{array}$ & 55,2 & 26,8 & 24,1 & 19,4 & 18,1 & 20,1 & 20,3 \\
$\begin{array}{l}\text { Kilka razy w } \\
\text { kwartale }\end{array}$ & 24,0 & 38,3 & 46,5 & 61,1 & 53,4 & 49,8 & 44,3 \\
$\begin{array}{l}\text { Kilka razy w roku i } \\
\text { rzadziej }\end{array}$ & - & - & - & - & 16,3 & 18,0 & 21,2 \\
\hline
\end{tabular}

Źródło: opracowanie własne na podstawie danych GUS (Ruch graniczny oraz przepływ...: 2011, 2012, 2013, Ruch graniczny oraz wydatki...: 2014, 2015, 2016, 2017).

W 2014 r. większość Rosjan przyjeżdżających do Polski na zasadach małego ruchu granicznego, przekraczała granicę kilka razy w miesiącu $(58,2 \%)$, zaś 21,8\% cudzoziemców przyjeżdżało do Polski kilka razy w tygodniu (Ruch graniczny oraz wydatki..., 2015). W 2015 r. w porównaniu do roku poprzedniego, zwiększył się o $0,5 \%$ udział osób przyjeżdżających codziennie oraz o 2\% przekraczających granicę kilka razy w tygodniu. Jednocześnie w ramach małego ruchu granicznego, zwiększył się o 0,7\% udział Rosjan przyjeżdżających do Polski codziennie oraz o 3,7\% przyjeżdżających kilka razy w tygodniu (Ruch graniczny oraz wydatki..., 2016).

Zawieszenie małego ruchu granicznego w 2016 r. wpłynęło na zmniejszenie udziału Rosjan przyjeżdżających codziennie do Polski. Konieczność posiadania wizy Schengen oraz procedury i opłaty związane z jej otrzymaniem, wpłynęły na wzrost udziału Rosjan przyjeżdżających do naszego kraju kilka razy w kwartale lub w roku. Podobnie jak w przypadku monitorowania celu przyjazdów, w 2017 r. w opracowaniach Głównego Urzędu Statystycznego nie ma statystyk dotyczących częstotliwości przyjazdów Rosjan do Polski.

$\mathrm{Na}$ granicy zewnętrznej Unii Europejskiej z Federacją Rosyjską zachodziły dynamiczne zmiany w wysokości i strukturze wydatków ponoszonych przez Rosjan w Polsce (Tab. 4).

W 2010 r. wydatki poniesione przez Rosjan w Polsce wyniosły 99,1 mln zł., z których ponad połowę przeznaczono na towary nieżywnościowe, $w$ tym: odzież i obuwie $-21,5 \%$, artykuły wyposażenia wnętrz - 9,4\% oraz części i akcesoria do środków transportu - 8,3\%. Na zakup towarów żywnościowych w Polsce, Rosjanie przeznaczali 26,8\% wydatków, z czego na zakup mięsa i wyrobów mięsnych $12,5 \%$. W grupie wydatków na inne cele dominowały wydatki na usługi gastronomiczne $(9,0 \%)$ i noclegowe $(5,4 \%)$ (Ruch graniczny oraz przepływ..., 2011).

W 2011 r. wydatki poniesione przez Rosjan w Polsce wzrosły o 89,8\% w porównaniu z 2010 r., a średnie wydatki przypadające na 1 cudzoziemca wzrosły o 31,7\%. Udział wydatków poniesionych na zakup towarów nieżywnościowych zwiększyły się o 4,6\%, 
natomiast nieznacznie zmniejszył się udział wydatków przeznaczonych na towary żywnościowe Wydatki na mięso i wyroby mięsne zmniejszyły się o 1,8\%, na warzywa, owoce i ich przetwory o $0,3 \%$. Wydatki poniesione przez Rosjan w Polsce na zakup odzieży i obuwia wzrosły o 14,3\%, a przeznaczone na środki czystości i kosmetyki o 1,3\% (Ruch graniczny oraz przepływ..., 2012).

Tabela 4. Wysokość i struktura wydatków poniesionych przez Rosjan w Polsce w latach 2010-2017

Table 4. The amount and structure of expenses incurred by the Russians in Poland in 2010-2017

\begin{tabular}{|c|c|c|c|c|c|c|c|c|}
\hline \multirow{2}{*}{$\begin{array}{c}\text { Wysokość i struktura } \\
\text { wydatków }\end{array}$} & \multicolumn{8}{|c|}{ Rok } \\
\hline & 2010 & 2011 & 2012 & 2013 & 2014 & 2015 & 2016 & 2017 \\
\hline Wydatki (mln zł) & 99,1 & 188,1 & 470,5 & 583,6 & 842,4 & 581,9 & 469,2 & 568,8 \\
\hline Średnie wydatki (zł) & 208 & 274 & 331 & 357 & 512 & 429 & 429 & 455 \\
\hline $\begin{array}{l}\text { Towary żywnościowe } \\
\text { (\%) }\end{array}$ & 26,8 & 26,2 & 28,8 & 33,7 & 15,3 & 28,5 & 28,5 & b.d. \\
\hline $\begin{array}{l}\text { Towary } \\
\text { nieżywnościowe (\%) }\end{array}$ & 56,4 & 61,0 & 55,5 & 53,9 & 62,3 & 57,1 & 58,8 & b.d. \\
\hline $\begin{array}{l}\text { Pozostałe wydatki - } \\
\text { usługi (\%) }\end{array}$ & 16,8 & 12,8 & 15,7 & 12,4 & 22,4 & 14,4 & 12,7 & b.d. \\
\hline
\end{tabular}

Źródło: opracowanie własne na podstawie danych GUS (Ruch graniczny oraz przepływ...: 2011, 2012, 2013, Ruch graniczny oraz wydatki...: 2014, 2015, 2016, 2017).

W 2012 r. wydatki poniesione przez Rosjan w Polsce wzrosły o 150,1\% w porównaniu z rokiem poprzednim, natomiast średnie wydatki przypadające na 1 osobę wzrosły o 20,8\%. Zwiększył się o 2,6\% udział wydatków poniesionych na towary żywnościowe oraz pozostałe wydatki (o 2,9\%), natomiast zmniejszył się o 5,5\% udział wydatków przeznaczonych na towary nieżywnościowe. Największy wzrost dotyczył wydatków na: mięso i wyroby mięsne $(2,6 \%)$, usługi noclegowe (o $2,5 \%)$, sprzęt RTV $(1,5 \%)$ oraz artykuły wyposażenia wnętrz $(1,2 \%)$ (Ruch graniczny oraz przepływ...,2013).

W 2013 r. wydatki poniesione przez Rosjan w Polsce wzrosły o 24\% w porównaniu z 2012 r. Średnie wydatki przypadające na 1 osobę wzrosły o 7,9\%. Wydatki Rosjan przekraczających granicę $\mathrm{w}$ ramach małego ruchu granicznego stanowiły $37,3 \%$ ogółu wydatków, i wzrosły o 13,6\% w porównaniu z rokiem poprzednim. W 2013 r. cudzoziemcy przeznaczali na towary nieżywnościowe 53,9\% ogółu wydatków (w małym ruchu granicznym $-50,5 \%)$, na towary żywnościowe $-33,7 \%(42,2 \%)$ oraz usługi $-12,4 \%$ (7,3\%). Największy spadek, w porównaniu z 2012 r. zanotowano w grupie pozostałych wydatków (o 21\%). Ponadto, wydatki na towary nieżywnościowe zmniejszyły się o 2,9\%, natomiast wydatki na towary żywnościowe zwiększyły się o 17\%. Największy wzrost wydatków odnotowano w następujących kategoriach: środki czystości i kosmetyki (wzrost o $3,1 \%)$, mięso i wyroby mięsne $(2,3 \%)$ oraz materiały budowlane $(0,4 \%)$. Jednocześnie, w 2013 r. zmniejszyły się wydatki na: odzież i obuwie (o 2,8\%), noclegi (1,7\%), usługi gastronomiczne $(1,3 \%)$ oraz części i akcesoria do środków transportu $(0,9 \%)$ (Ruch graniczny oraz przepływ..., 2014).

Na wzrost aktywności nabywczej i wydatków ponoszonych przez Rosjan w Polsce, wpłynęły ułatwienia w przekraczaniu granicy oraz opłacalność zakupów. Wielu mieszkańców obszarów przygranicznych przyjeżdżało do Polski w celu zakupu produktów rolno-spożywczych, których ceny na terenie Obwodu Kaliningradzkiego były kilkakrotnie wyższe. Z badań przeprowadzonych przez Centrum Polsko-Rosyjskiego Dialogu 
i Porozumienia, wynika że w pierwszym roku funkcjonowania małego ruchu granicznego Rosjanie najczęściej kupowali w Polsce żywność (86\% wskazań), sprzęt RTV i AGD (32\%) oraz odzież i obuwie - 29\% (Mały ruch w dobrym kierunku, 2013).

Zaopatrzenie rynku oraz jakość towarów rolno-spożywczych są w Polsce na zdecydowanie wyższym poziomie niż w Rosji. Ponadto, jakość produktów spożywczych Rosji, głównie mięsa i jego przetworów jest zdecydowanie niższa niż w Polsce. Znajomość kraju pochodzenia produktu była głównym determinantem zakupu. Z badań Walaszczyk i Ordzińskiego (2014) wynika, że konsumenci chcą wiedzieć, z jakiego kraju pochodzi żywność i z jakich surowców została wyprodukowana. Informacje na etykiecie dotyczące pochodzenia produktu, mogą wpływać na zwiększenie popytu.

W 2014 r. wydatki poniesione przez Rosjan w Polsce wzrosły o 44,3\% w porównaniu $\mathrm{z}$ rokiem poprzednim, a średnie wydatki wzrosły o $43,4 \%$. Wydatki poniesione w Polsce przez cudzoziemców przekraczających granicę $\mathrm{w}$ ramach małego ruchu granicznego stanowiły 48,6\% ogółu wydatków i wzrosły o $88,2 \%$ w porównaniu z 2013 r. W związku $\mathrm{z}$ wprowadzeniem ograniczeń $\mathrm{w}$ imporcie do Federacji Rosyjskiej, towarów rolnospożywczych z Polski, istotnym zmianom uległa struktura nabywanych przez Rosjan towarów i usług. Zmniejszył się o 18,4\% udział wydatków poniesionych przez Rosjan w Polsce na zakup towarów żywnościowych, natomiast wzrósł o 8,4\% udział wydatków na towary nieżywnościowe oraz o $10 \%$ udział wydatków poniesionych na inne cele (w tym usługi). Cudzoziemcy przekraczający granicę $w$ ramach małego ruchu granicznego, najwięcej wydali na towary nieżywnościowe $(54,9 \%)$, w dalszej kolejności na żywność $29,4 \%$ oraz na usługi $-15,7 \%$ (Ruch graniczny oraz wydatki..., 2015).

Zachowania Rosjan na polskim rynku towarów rolno-spożywczych warunkowane były decyzjami politycznymi. Obowiązujący od 1 stycznia 2014 r. zakaz wwozu do Federacji Rosyjskiej, m.in. mięsa i jego przetworów, mleka i produktów mlecznych oraz owoców i warzyw, dotyczy również osób indywidualnych, które mogą wwieźć produkty pochodzenia zwierzęcego w opakowaniach hermetycznych, w ilości nie przekraczającej $5 \mathrm{~kg}$. Wprowadzone przez Federację Rosyjską embargo wpłynęło także na wzrost cen towarów w Obwodzie Kaliningradzkim. Jak wskazuje w swoim raporcie Afanasenko (2015) po wprowadzeniu embargo, Rosjanie masowo wykupywali ze sklepów w Obwodzie Kaliningradzkim znane produkty pochodzące $\mathrm{z}$ importu, spodziewając się dużych podwyżek cen żywności. Ponadto, w 2014 r. konsumenci rosyjscy ograniczyli częstotliwość zakupów oraz wydatki na zakup towarów spożywczych. W sierpniu 2014 r. ceny produktów żywnościowych w Obwodzie Kaliningradzkim kształtowały się na poziomie: jabłka - 70-90 rubli/kg (wzrost o $130-200 \%$ w porównaniu do analogicznego okresu 2013 r.), cebula - 70 rubli (wzrost o ok. 17\%), ser żółty - 400-500 rubli/kg (wzrost o ok. 120-180\%), masło - 100-120 rubli/200 g (wzrost o ok. 45-75\%), parówki - 200-250 rubli/kg (wzrost o ok. 100-200\%). W związku z powyższym, wielu mieszkańców Obwodu Kaliningradzkiego decydowało się na zakup żywności w Polsce. Jednakże obawy Rosjan przed kontrolami granicznymi stały się na tyle silne, że spowodowały znaczne ograniczenie zakupu w Polsce towarów pochodzenia zwierzęcego, takich jak: mięso i jego przetwory oraz mleko i produkty mleczne.

W 2015 r. wydatki poniesione przez Rosjan w Polsce zmniejszyły się w porównaniu z 2014 r. o 30,9\%. Wydatki Rosjan przekraczających granicę w ramach małego ruchu granicznego stanowiły $49,1 \%$ ogółu wydatków i zmniejszyły się o $30,2 \%$ w porównaniu z rokiem poprzednim. Najwięcej wydatków cudzoziemcy przeznaczyli na zakup towarów nieżywnościowych $(57,1 \%)$, na produkty żywnościowe $-28,5 \%$, a na usługi $-14,4 \%$. 
Struktura wydatków Rosjan przekraczających granicę w ramach małego ruchu granicznego była bardzo podobna i przedstawiała się następująco: towary nieżywnościowe $-57,5 \%$, produkty żywnościowe - 32,6\%, usługi - 9,9\% (Ruch graniczny oraz wydatki..., 2016).

W 2016 r. wydatki poniesione przez Rosjan w Polsce zmniejszyły się w porównaniu z rokiem poprzednim o $19,4 \%$, natomiast średnie wydatki przypadające na 1 cudzoziemca zmniejszyły się o 0,2\% (Ruch graniczny oraz wydatki..., 2017). Wartość wydatków Rosjan przekraczających granicę polsko-rosyjską w ramach małego ruchu granicznego w I kw. 2016 r. ukształtowała się na poziomie $47,7 \mathrm{mln}$ zł, co stanowiło $45,2 \%$ ogółu wydatków cudzoziemców przekraczających ten odcinek granicy. Wydatki te były mniejsze o $35,7 \%$ w porównaniu z IV kw. 2015 r. i o 23,9\% niż w I kw. 2015 r. Średnie wydatki poniesione w Polsce przez cudzoziemca przekraczającego granicę polsko-rosyjską w ramach małego ruchu granicznego w I kw. 2016 r. wyniosły 379 zł, i były mniejsze o 18,8\% w porównaniu z IV kw. 2015 r. oraz o 18,1\% niż w analogicznym okresie 2015 r. (Ruch graniczny oraz wydatki w I kw. 2016 r., 2016).

Wydatki Rosjan przekraczających granicę polsko-rosyjską w ramach małego ruchu granicznego w II kw. 2016 r. wyniosły 65,0 mln zł, co stanowiło 49,3\% ogółu wydatków cudzoziemców przekraczających ten odcinek granicy. Wydatki te były wyższe o $36,3 \%$ niż w poprzednim kwartale i o 19,6\% niższe niż w analogicznym okresie 2015 r. Średnie wydatki poniesione w Polsce przez cudzoziemca przekraczającego granicę polsko-rosyjską w ramach małego ruchu granicznego w II kw. 2016 r. wyniosły 401 zł., i były wyższe o 5,8\% w porównaniu z I kw. 2016 r. oraz niższe o 4,3\% niż w II kw. 2015 r. (Ruch graniczny oraz wydatki w II kw. w 2016 r., 2016).

W 2017 r. pomimo zawieszenia małego ruchu granicznego, odnotowano wzrost wydatków poniesionych przez Rosjan w Polsce $21,2 \%$ oraz wzrost średnich wydatków o 6,1\%. Zróżnicowanie wydatków, zarówno pod względem ich wysokości, jak i struktury, związane było przede wszystkim z celem podróży, długością pobytu, oraz opłacalnością dokonywania zakupów w Polsce.

Po analizie ruchu granicznego, wyrażanej intensywnością przekraczania przez Rosjan granicy polsko-rosyjskiej oraz wielkością i strukturą wydatków ponoszonych w Polsce, można przypuszczać, że atrakcyjność naszego kraju, postrzegana była przez pryzmat możliwości zakupu towarów i usług wysokiej jakości w korzystnych cenach. W badaniach przeprowadzonych w 2014 r. przez Ogólnorosyjskie Centrum Badania Opinii Publicznej, 82\% Rosjan uznało Polskę za miejsce, w którym kupić można towary o wysokiej jakości i korzystnych cenach, 78\% określiło nasz kraj jako miejsce, gdzie można dobrze i smacznie zjeść, a 75\% postrzegało Polskę jako cel wyjazdów turystycznych (Mały ruch w dobrym kierunku..., 2014).

Rosjanie dokonujący zakupów w Polsce, korzystają z możliwości uzyskania zwrotu podatku VAT. System Tax Free umożliwia zwrot podatku VAT za transakcje przekraczające wartość 300 zł. Z informacji Izby Celnej w Olsztynie wynika, że z roku na rok na przejściach granicznych Polski z Rosją, odnotowywano wzrost liczby oraz wartości zgłoszonych przez Rosjan rachunków (Tab. 5). Na granicy polsko-rosyjskiej do 2014 r., następował wzrost liczby oraz wartości zgłoszonych przez Rosjan rachunków Tax Free. Wydatki Rosjan na zakup towarów w Polsce były dużo wyższe, ponieważ nie wszystkie placówki i sieci handlowe wystawiały faktury VAT, np. przedsiębiorstwo Jeronimo Martins, będące właścicielem sieci handlowej Biedronka, rozpoczęło wydawanie stosownych dokumentów dopiero w grudniu $2014 \mathrm{r}$. 
Tabela 5. Liczba i wartość rachunków Tax Free zgłoszonych przez Rosjan na granicy polsko-rosyjskiej od 27.07.2012 do31.12.2017

Table 5. The number and value of the tax-free accounts reported by the Russians on the Polish-Russian border from July 27, 2012 to December 31, 2017

\begin{tabular}{l|cc}
\hline & Liczba rachunków & Wartość rachunków (zł) \\
\hline 27.07. -31.12.2012 r. & 18733 & 19089620 \\
$01.01 .-31.12 .2013 \mathrm{r}$. & 114765 & 94680834 \\
$01.01 .-31.12 .2014 \mathrm{r}$. & 188456 & 144165666 \\
$01.01 .-31.12 .2015 \mathrm{r}$. & 174646 & 134959326 \\
$01.01 .-30.06 .2016 \mathrm{r}$. & 75243 & 65840930 \\
$01.07 .-31.12 .2016 \mathrm{r}$. & 79386 & 88052640 \\
$01.01 .-31.12 .2017 \mathrm{r}$. & 201015 & 198700000 \\
\hline
\end{tabular}

Źródło: opracowanie własne na podstawie Informacji Izby Celnej w Olsztynie... 2017, Informacji Izby Celnej w Olsztynie..., 2018.

W 2015 r. polskie służby celne zarejestrowały o 7,3\% mniej rachunków zgłoszonych przez Rosjan, których wartość była niższa o 6,4\%. Zmniejszenie liczby i wartości zgłoszonych dokumentów Tax Free, była skutkiem spadku siły nabywczej rosyjskiej waluty, co w konsekwencji doprowadziło do zmniejszenia opłacalności zakupów w Polsce.

W 2016 r. odnotowano dalszy spadek liczby zgłoszonych dokumentów Tax Free o 11,5\%, natomiast o 14\% wzrosła wartość rachunków. Paradoksalnie, po zawieszeniu przepisów Umowy o małym ruchu granicznym na granicy polsko-rosyjskiej, w porównaniu do I połowy roku, służby celne zarejestrowały o 5,5\% więcej rachunków na kwotę wyższą o $33,7 \%$. Swiadczy to o zmianie preferencji nabywczych Rosjan, którzy w Polsce coraz częściej nabywali towary luksusowe.

W 2017 r. nastapił wzrost liczby zgłoszonych rachunków Tax Free o 30\% oraz wartości tych rachunków o 29,1\%. Z informacji przekazanej przez służbę celną wynika, że pomimo obowiązującego embargo na polskie towary rolno-spożywcze oraz zakazu wwozu do Federacji Rosyjskiej produktów pochodzenia zwierzęcego w ilości przekraczającej $5 \mathrm{~kg}$, Rosjanie kupowali w Polsce dużo produktów spożywczych, najwięcej jednak hermetycznie pakowanych wędlin i mięsa, mleko w kartonach, jogurty i serki oraz twarogi. Dużym zainteresowaniem cieszyła się żywność dla dzieci i niemowląt: kaszki, przeciery, gotowe posiłki w słoiczkach. Pomimo niekorzystnego przekazu medialnego na temat polskich towarów rolno-spożywczych, głównie mięsa i jego przetworów, Rosjanie doceniają wysoką jakość żywności oraz jej atrakcyjną cenę. Pomimo stosowanych przez Rosję utrudnień o charakterze para- i pozataryfowym, polskie produkty rolno-spożywcze pozostają na tym rynku relatywnie wysoko konkurencyjne (Kita, Poczta, 2012).

Z informacji polskich służb celnych wynika, że Rosjanie przewożą do Rosji bardzo dużo odzieży i obuwia, sprzęt AGD, (miksery, sokowirówki itp.), sprzęt RTV (głównie telewizory), a także telefony komórkowe. Często zgłaszają przewóz części samochodowych i materiałów eksploatacyjnych do pojazdów. Znacząco wzrosło zainteresowanie Rosjan zakupem w Polsce towarów wyższego rzędu: biżuterii, galanterii skórzanej i elektroniki. Odnotowano wiele zgłoszeń towarów luksusowych, np. torebek damskich w cenie ok. 100 tys. zł. za sztukę czy zegarków firmy Rolex za ponad 25 tys. euro. W 2017 r. Rosjanie nabywali w Polsce bardzo dużo sprzętu elektronicznego, począwszy od smartfonów, po 
routery, laptopy, konsole do gier, smartwatche, wirtualne okulary oraz telewizory (Informacja Izby Celnej w Olsztynie..., 2018). Informacje te stanowią potwierdzenie rezultatów badań przeprowadzonych przez firmę Landor w 2014 r., z których wynika, że wbrew stereotypom, Rosjanie coraz bardziej koncentrowali uwage na towarach wysokiej jakości, produktach premium, towarach luksusowych, preferując jednocześnie marki w takich kategoriach produktów, jak: odzież i obuwie, kosmetyki, elektronika oraz samochody (Beckmann, 2014).

Należy jednocześnie zwrócić uwagę, że zwrot podatku VAT nie przysługuje za usługi, takie jak: posiłki $\mathrm{w}$ restauracji, noclegi $\mathrm{w}$ hotelu, zabiegi SPA itp. Można więc przypuszczać, że Rosjanie wydają w Polsce znacząco więcej pieniędzy, niż wynika ze zgłoszonych na granicy polsko-rosyjskiej rachunków Tax Free.

\section{Podsumowanie}

Zachowania Rosjan na rynku polskim są kształtowane przez procesy globalizacyjne, integracyjne, a także internacjonalizację życia. Na granicy zewnętrznej Unii Europejskiej z Federacją Rosyjską zachodziły dynamiczne zmiany w poziomie natężenia ruchu granicznego oraz wydatkach ponoszonych przez Rosjan w Polsce. Wpływ na te zmiany miały m.in. przepisy regulujące zasady funkcjonowania ruchu granicznego między Rzeczypospolitą Polską a Federacją Rosyjską, relacje cenowe pomiędzy sąsiadującymi krajami, a ostatnio również - niestabilna sytuacja międzynarodowa. Wszelkie zmiany przepisów regulujących przepływ towarów i usług na granicy polsko-rosyjskiej, natychmiast znalazły odzwierciedlenie $\mathrm{w}$ poziomie natężenia ruchu granicznego, celu i częstotliwości przyjazdu Rosjan do Polski oraz w wysokości wydatków poniesionych w naszym kraju.

Czynnikiem powodującym zmniejszenie ruchu osobowego na granicy polskorosyjskiej oraz zmiany w strukturze wydatków ponoszonych przez Rosjan, było embargo wprowadzone przez Federację Rosyjską na produkty rolno-spożywcze z krajów Unii Europejskiej oraz osłabienie wartości rubla. Spadek siły nabywczej waluty rosyjskiej wpłynął na zmniejszone zainteresowanie zakupami w Polsce, jednakże ceny polskich towarów i usług nadal były niższe od cen w Rosji.

Po wprowadzeniu ograniczeń $\mathrm{w}$ przewozie produktów pochodzenia zwierzęcego nastapiły zmiany w strukturze towarów nabywanych przez Rosjan w Polsce. Zwiększyło się zainteresowania Rosjan zakupem towarów wyższego rzędu, o czym może świadczyć zwiększająca się z roku na rok wartości rachunków Tax Free zgłoszonych na granicy. Zachowania Rosjan wskazują na dążenie do osiągania pożądanego statusu, określonego poziomem aspiracji oraz posiadaniem towarów luksusowych.

Wiedza o zachowaniach Rosjan powinna stanowić dla przedsiębiorców polskich ważny element służący do planowania $\mathrm{i}$ realizowania współpracy $\mathrm{z}$ podmiotami reprezentującymi rynek rosyjski. Nabiera ona tym większego znaczenia w perspektywie planów i działań podmiotów działających w warunkach istniejącego ryzyka politycznego, które w istotny sposób oddziaływuje na zachowania konsumentów na rynkach przygranicznych. Przesłanki ekonomiczne dominujące w decyzjach nabywczych Rosjan ulegaja zmianom pod wpływem warunków gospodarczo-społecznych. W strategii prowadzenia działalności handlowo-usługowej skierowanej do Rosjan, należy uwzględnić bodźce i ograniczenia zewnętrzne, które determinują ich decyzje nabywcze. Dynamika 
sytuacji, w której funkcjonuje konsument rosyjski jest niezwykle ważnym elementem w modyfikowaniu jego zachowań. Przedsiębiorcy muszą zdać sobie sprawę, że konsumenci rosyjscy są zorientowanymi nie tylko na cenę, ale również na charakterystykę produktu. Ich preferencje kierują się w stronę takich kryteriów, jak: potrzeba podkreślania prestiżu i zamożności oraz wyróżniania się poprzez posiadanie dóbr luksusowych.

\section{Literatura}

Afanasenko, I. (2015). Consumer Trends in Food and Retail Sector. USDA Foreign Agricultural Service, Global Agricultural Information Network, St. Petersburg. Pobrane 7 czerwca 2018 r. z: https://gain.fas.usda.gov/Recent\%20GAIN\%20Publications/Consumer\%20Trends $\% 20$ in $\% 20$ Food $\% 20$ and $\%$ 20Retail\%20Sector_St.\%20Petersburg_Russian\%20Federation_2-17-2015.pdf.

Anczakowska, L. (2016). Rosyjska gospodarka - informacje sygnalne (Russian economy - signal information). РОССИЯ Twój Rynek, 3-4, 3-14.

Barczyk, R. (2014). Pieniądz w modelach cykli koniunkturalnych (Money in business cycle models). W: J. Stecewicz (red.) Polityka gospodarcza jako gra w wyzwania i odpowiedzi rozwojowe. Prace i Materiały Instytutu Rozwoju Gospodarczego SGH, 103-128.

Beckmann, E. (2014). Landor's Russian Consumer Report. Landor, Moscow. Pobrane 3 czerwca 2018 r. z: http://landor.com/thinking/landors-russian-consumer-report-an-introduction.

Centrum Polsko-Rosyjskiego Dialogu i Porozumienia (2013). Mały ruch w dobrym kierunku (Small border traffic in the right direction). Warszawa.

Centrum Polsko-Rosyjskiego Dialogu i Porozumienia (2014). Mały ruch w dobrym kierunku. Współpraca rosyjsko-polska według mieszkańców Obwodu Kaliningradzkiego objętych programem małego ruchu granicznego (Small border traffic in the right direction. Russian-Polish cooperation according to the inhabitants of the Kaliningrad Oblast covered by the local border traffic program). Warszawa.

Dz.U. z dnia 16 lipca 2012 r. poz. 814 (2012). Umowa między Rządem Rzeczypospolitej Polskiej a Rządem Federacji Rosyjskiej o zasadach małego ruchu granicznego (Agreement between the Government of the Republic of Poland and the Government of the Russian Federation on the principles of local border traffic). http://prawo.sejm.gov.pl/isap.nsf/DocDetails.xsp?id=WDU20120000814 (dostęp: 2.07.2018).

Fundacja im. Stefana Batorego (2008). Monitoring przejść granicznych Unii Europejskiej. Raport z badań. 2008. (Monitoring of European Union border crossings. Research report. 2008). Warszawa. http://www.batory.org.pl/upload/files/pdf/monitoring_przejsc_granicznych_ue.pdf (dostęp: 25.02.2016).

Garbarski, L., Rutkowski, I., Wrzosek, W. (2000). Marketing (Marketing). PWE, Warszawa.

Główny Urząd Statystyczny, Urząd Statystyczny w Rzeszowie (2011). Ruch graniczny oraz przepływ towarów i usług na zewnętrznej granicy Unii Europejskiej na terenie Polski w 2010 r. (Border traffic and movement of goods and services at the European Union's external order on the territory of Poland in 2010). WarszawaRzeszów.

Główny Urząd Statystyczny, Urząd Statystyczny w Rzeszowie (2012). Ruch graniczny oraz przepływ towarów i usług na zewnętrznej granicy Unii Europejskiej na terenie Polski w 2011 r. (Border traffic and movement of goods and services at the European Union's external order on the territory of Poland in 2011). WarszawaRzeszów.

Główny Urząd Statystyczny, Urząd Statystyczny w Rzeszowie (2013). Ruch graniczny oraz przepływ towarów i usług na zewnętrznej granicy Unii Europejskiej na terenie Polski w 2012 r. (Border traffic and movement of goods and services at the European Union's external order on the territory of Poland in 2012). WarszawaRzeszów.

Główny Urząd Statystyczny, Urząd Statystyczny w Rzeszowie (2014). Ruch graniczny oraz przepływ towarów i usług na zewnętrznej granicy Unii Europejskiej na terenie Polski w 2013 r. (Border traffic and movement of goods and services at the European Union's external order on the territory of Poland in 2013). WarszawaRzeszów.

Główny Urząd Statystyczny, Urząd Statystyczny w Rzeszowie (2015). Ruch graniczny oraz wydatki cudzoziemców w Polsce i Polaków za granicą w 2014 r. (Border traffic and expenses made by foreigners in Poland and Poles abroad in 2014). Warszawa-Rzeszów.

Główny Urząd Statystyczny, Urząd Statystyczny w Rzeszowie (2016). Ruch graniczny oraz wydatki cudzoziemców w Polsce i Polaków za granica w 2015 r. (Border traffic and expenses made by foreigners in Poland and Poles abroad in 2015). Warszawa-Rzeszów. 
Główny Urząd Statystyczny (2016). Ruch graniczny oraz wydatki cudzoziemców w Polsce i Polaków za granicą w I kwartale 2016 r. (Border traffic and expenses made by foreigners in Poland and Poles abroad in the I quarter 2016). Warszawa.

Główny Urząd Statystyczny (2016). Ruch graniczny oraz wydatki cudzoziemców w Polsce i Polaków za granica w II kwartale 2016 r. (Border traffic and expenses made by foreigners in Poland and Poles abroad in the II quarter 2016). Warszawa.

Główny Urząd Statystyczny, Urząd Statystyczny w Rzeszowie (2017). Ruch graniczny oraz wydatki cudzoziemców w Polsce i Polaków za granica w 2016 r. (Border traffic and expenses made by foreigners in Poland and Poles abroad in 2016). Warszawa-Rzeszów.

Gruenewald, P.J., Johnson, F.W., Treno, A. (2002). Outlets, drinking and driving: a multilevel analysis of availability. Journal of Student Alcohol, 63, 460-467.

Grzega, U., Kieżel, E. (2017). Trendy w zachowaniach konsumentów (Trends in consumer behavior). W: M. Bartosik-Purgat (red.) Zachowania konsumentów. Globalizacja, nowe technologie, aktualne trendy, otoczenie społeczno-kulturowe Warszawa. PWE, s. 31-51.

Izba Celna w Olsztynie (2017). Wartość rachunków krajowych zarejestrowanych w Oddziałach Celnych na granicy polsko-rosyjskiej (The value of national accounts registered in Customs Branches at the PolishRussian border). Olsztyn.

Izba Celna w Olsztynie (2018). Wartość rachunków krajowych zarejestrowanych w Oddziałach Celnych na granicy polsko-rosyjskiej (The value of national accounts registered in Customs Branches at the PolishRussian border). Olsztyn.

Kasouf, Ch., Nikitina, S. (2013). Consumer research to revitalize a Russian Brand. Worcester Polytechnic Institute.

Kaynak, E., Kucukemiroglu, O., Hyder, A.S. (2000). Consumers' Country-of-origin (COO) Perceptions of Imported Products in a Homogenous Less-developed Country. European Journal of Marketing, 34 (9/10), 1221-1241.

Kita, K., Poczta, W. (2012). Pozycja konkurencyjna polskiego sektora rolno-żywnościowego na rynkach krajów Wspólnoty Niepodległych Państw (Competitive position of the Polish agri-food sector in the Commonwealth of Independent States market). ZN SGGW Problemy Rolnictwa Światowego, 14(4), 65-76.

Komenda Główna Straży Granicznej. Biuletyn Straży Granicznej. Pobrane 5 czerwca 2018 r. z: https://www.strazgraniczna.pl/pl/granica/ statystyki-sg/2206,Statystyki-SG.html.

Pesu, S. (2013). Consumer Behaviour in Russia. Pobrane 31 stycznia 2017 r. z: https://www.awaragroup.com/upload/pdf/Awara-Group-Consumer-Behaviour-in-Russia.pdf.

Powęska, H. (2011). Functions of retail trade in the borderlands of Poland - a theoretical perspective. Acta Scientiarum Polonorum Oeconomia, 10(2), 65-74.

Powęska, H. (2014). Udział nierejestrowanych zakupów artykułów nieżywnościowych w obrotach handlowych Polski z Ukraina, Białorusia Rosją (The share of unregistered purchases of non-food products in Poland's trade turnover with Ukraine, Belarus and Russia). Roczniki Naukowe SERiA, 16(3), 236-241.

Reardon, J., Miller, Ch., Vida, I., Kim, I. (2005). The Effects of Ethnocentism and Economic Development on the Formation of Brand and ad Attitudes in Transitional Economies. European Journal of Marketing, 39, $737-754$.

Russia: Reaching the consumer. (2017). Pobrane 31 stycznia 2017 r. z: https://en.portal.santandertrade.com/ analyse-markets/russia/reaching-the-consumers.

Samiec, S. (1994). Customer Evaluation of Products in a Global Market. Journal of International Business Studies, 25 (3), 570-604.

Sharma, P., Wu, Z. (2015). Consumer Ethnocentrism vs. Intercultural Competence as Moderators in Intercultural Service Encounters. Journal of Services Marketing, 29, 93-102.

Studzińska, D.B., Rzyski, S. (2015). Transformacja granicy i jej oddziaływanie na region. Pogranicze polskorosyjskie po wejściu życie małego ruchu granicznego (Border transformation and its impact on the region. The Polish-Russian borderland after entering the life of small border traffic). Annales Universitatis Mariae Curie-Skłodowska Lublin-Polonia, LXX (2), 179-190.

Szczepanik, K. (2013). Drożyzna w rosyjskich sklepach - gubernator bije pięścią w stół, a polscy handlowcy zacieraja rece (It is expensive in Russian stores - the governor beats his fist on the table, and Polish traders rub their hands). Pobrane 20 stycznia 2017 r. z: http://www.europamaxima.eu/publikacje/86/56/Drozyzna-wrosyjskich-sklepach-gubernator-bije-piescia-w-stol-a-polscy-handlowcy-zacieraja-rece.

Walaszczyk, A., Ordziński, M. (2014). Znaczenie zarządzania identyfikowalnością wyrobów spożywczych dla konsumentów - badania analizy. (The importance of traceability management food products for consumers - research and analysis). ZN SGGW Problemy Rolnictwa Światowego, 14(3), 177-185. 
Wang, C., Chen, Z. (2004). Consumer Ethnocentrism and Willingness to Buy Domestic Products in a Developing Country Setting: Testing Moderation Effects. International of Consumer Marketing, 21(6), 391-400.

Zhou, L., Yang, Z., Hui, K. (2010). Non-Local Brands? A Multi-Level Investigation into Confidence in Brand Origin Identification and Its Strategic Implications. Journal of the Academy of Marketing Science, 38(2): 202-218.

Żukowski, A. (2013). Mały ruch graniczny między Polską a Rosją - wstępne konkluzje (Small border traffic between Poland and Russia - preliminary conclusions). W: W. Kotowicz., W.T. Modzelewski, A. Żukowski (red.). Polska polityka wschodnia a współpraca zagraniczna województwa warmińsko-mazurskiego. Instytut Nauk Politycznych Uniwersytetu Warmińsko-Mazurskiego, Olsztyn, s. 55-63.

Лукьянова, Н.Ю. (2015). Моделирование потребителского спроса на продукты питания в Калининградской области (Modeling consumer's food for food in the Kaliningrad Region). Вестник Балтийского Федерального Университета им. И. Канта, 3, 77-83.

Национальное Рейтинговое Агентство (2014). Сельское хозяйство в России: итоги 2014 г.(Agriculture in Russia: the results of 2014). Pobrano 25 marca 2017 r. z: http://www.ra-national.ru/sites/default/files/sel hoz_2014.pdf.

Никифорова, И.В., Огнева, Н.Ф. (2014). Оценка уровня потребления продовольствия как основы обеспечения продовольственной безопасности на примере Калининградской области (Estimation of the level of food consumption as a basis for ensuring food security on the example of the Kaliningrad region). Молодой ученый, 19 (78), 27-30.

Никифорова, И.В. (2015). Импортная продовольственная зависимость как угроза продовольственной безопасности калининградской области (Imported food dependence as a threat to food security in the Kaliningrad region). Вестник Балтийского Федерального Университета им. И. Канта, 3, 84-90.

Федеральная Таможенная Служба (2015). Товары для личного пользования, перемещаемые через таможенную границу, с освобождением от уплаты таможенных платежей (Goods for personal use, transported across the customs border, with exemption from customs payments.). Pobrano 31 stycznia 2017 z: http://fl.customs.ru/index.php?option=com_content\&view=article\&id=95:2015-12-09-11-56-14\&catid=5: 2008-10-20-15-38-16\&Itemid=1795.

Do cytowania / For citation:

Batyk I.M. (2018). Wybrane wskaźniki zachowań Rosjan na rynku polskim ze szczególnym uwzględnieniem rynku rolno-spożywczego w latach 2010-2017. Problemy Rolnictwa Światowego, 18(3), 7-22; DOI: 10.22630/PRS.2018.18.3.62

Batyk I.M. (2018). Selected Factors of Russian Behavior on the Polish Market with Particular Regard to the Agri-Food Market in 2010-2017 (in Polish). Problems of World Agriculture, 18(3), 7-22;

DOI: 10.22630/PRS.2018.18.3.62 